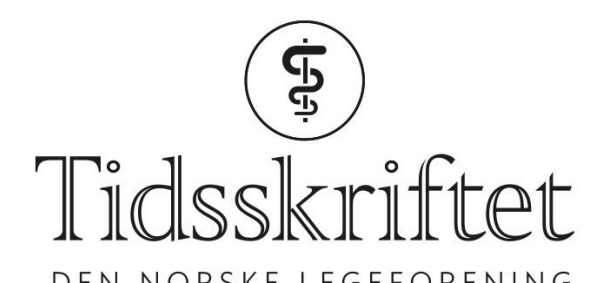

DEN NORSKE LEGEFORENING

\title{
Rettelse: Lungekreftforekomst knyttet til radoneksponering i norske boliger
}

RETTELSE

CHRISTINA SøYLAND HASSFJELL

TOM KRISTIAN GRIMSRUD

WILLIAM J.F. STANDRING

STEINAR TRETLI

Tidsskr Nor Legeforen 2017; 137: 1038-42.

I oversettelsen av artikkelen Lungekreftforekomst knyttet til radoneksponering i norske boliger, publisert på tidsskriftet.no, skal tittelen lyde:

Lung cancer incidence associated with radon exposure in Norwegian homes

Videre skal det i samme artikkel stå:

Conversely, an elimination of radon in all Norwegian homes in the long term will result in a significant reduction in the incidence of lung cancer (12\%), even in the face of unchanged smoking habits.

Vi beklager feilen, den er rettet på nett.

Publisert: 8. oktober 2018. Tidsskr Nor Legeforen. DOI: 10.4045/tidsskr.18.0755

(C) Tidsskrift for Den norske legeforening 2020. Lastet ned fra tidsskriftet.no 